\title{
Resources Integration Model of University Marxism Education from New Media Perspective
}

\author{
LiYating \\ Nanchang Institute of Science \&Technology,Nanchang 330108,China
}

\begin{abstract}
Keywords: New media; University Marxism education; Resource integration mode; Fuzzy evaluation method
\end{abstract}

\begin{abstract}
New media uses its diversified way to show people a rich image of the education theme and content, as well as breaking the traditional geographical and temporal and spatial limitations, conveying a wealth of resources for the audience with the vast amounts of knowledge and information. Marxism education in such a stage with so much concern will be with the integration of new media to achieve a fundamental change, and new media in Marxism education resource integration can not only enrich the Marxism education way to expand the educational approaches of Marxism education, beautify the environment of Marxism education, but also integrate Marxism education platform for resource sharing and optimization configuration. We should fully use new media technologies to effectively apply it to University Marxism education resource integration, so that University Marxism education is no longer limited to a single mentoring taught, but by means of new media, with a visual and auditory feast effects to realize University students' Marxism education cultivation, which can not only speed up and improve the efficiency, but also realize sharing and utilization of social resources and better able to achieve economic and social optimization. We will fully will new media technology to apply them effectively in college Marxism education resource integration, makes the Marxism education in Colleges and universities are no longer limited to single mentoring teaching, but with the help of new media, visual, auditory feast has effect to realize the college students Marxism cultivation, enhance students' Marxism quality, improve the efficiency of Marxism education.
\end{abstract}

\section{Introduction}

In the pursuit of a comprehensive development at the same time, people pay more and more attention to college students' Marxism quality, pay attention to the Marxism education in Colleges and universities[1,2]. But in the traditional Marxism education system, the Marxism education is not optimistic, education effect is not good. University Marxism education resources which aspect to have? How to make Marxism education resources to maximize utility? It needs to integrate resources of Marxism education in Colleges and universities[3,4]. In today's society, the computer network technology and information communication technology the rapid development of the times, these new technology brings new media medium with across time and space characteristics. These new media is not only in the form of the text appears, more is illustrated in the form of video, audio, images, and other diversity richness, can make information resources free transfer and learning, realization of spatial coexistence of old and new media[5]. New media can not only realize the Marxism education resources integration, but also for the Marxism education in Colleges and universities to bring more advanced methods and technology, realize the education of host-guest interaction, stimulate students to participate the interest of Marxism education, create good atmosphere of Marxism education in Colleges and the society, to set up communication between the bridge, the realization of Marxism education in the education of diversity and diversification, improve the effect of Marxism education[6]. 


\section{Literature overview and research methods}

Marxism education, is currently the University and the community generally the focus of attention. The actual effect of Marxism education, is inseparable from the resources of Marxism education. The so-called Marxism resources, refers to the activities of Marxism education, to be educated for the development and utilization of Marxism practice, to ensure that the Marxism education objective, conducive to the realization of the various elements of the sum of. University Marxism education resources with which to have? How will the university Marxism education resource to be exploited, we will continue to think and solve key. In fact, Marxism education in Colleges and universities is the vast resources of a system. This paper argues that the Marxism resources by University College material resources, cultural resources and the human resources in Colleges and universities is composed of three parts. College material resources mainly embodied in the physical, financial and educational infrastructure, property, by the media, classroom, campus infrastructure. College cultural resources is a college for students to create a culture of learning, comprehensive development place and atmosphere. The human resources in Colleges and universities is mainly reflected in the college staff and students' potential and practical ability. To make Marxism education resources play the greatest effectiveness, need all of the resources to be integrated using.

This paper uses fuzzy evaluation method, first make clear the evaluation of the evaluation factor set $\mathrm{F}$, then we make the evaluation index factors as $\mathrm{m}$, and then we can get[7]

$$
\mathbf{F}=\left(f_{1}, f_{2}, \ldots \ldots f_{m}\right)
$$

In formula (1), $f_{i}$ represents individual evaluation factor indicator.

Then we have to determine the evaluation set of indicators corresponding to the evaluation factor $\mathrm{W}$, and the evaluation level is determined as $\mathrm{n}$, then we can get[8]

$$
W=\left(w_{1}, w_{2}, \ldots . . w_{n}\right)
$$

Third, through expert evaluation factor indicator scoring, we make claer the weight set A.

Fourth, we build the evaluation matrix[9]

$$
T=\left[\begin{array}{cccc}
t_{11} & t_{12} & \ldots & t_{1 n} \\
t_{21} & t_{22} & \ldots & t_{2 n} \\
\vdots & \vdots & & \\
t_{m 1} & t_{m 2} & \ldots & t_{m n}
\end{array}\right]
$$

In formula (13), $t_{i j}$ is the evaluation factor index $f_{i}$ corresponding to the jth evaluation value.

Fifth, we make this comprehensive evaluation.[10]

$$
\left(b_{1}, b_{2}, \ldots, b_{n}\right)=\left(a_{1}, a_{2}, \ldots a_{m}\right) \times\left[\begin{array}{cccc}
t_{11} & t_{12} & \ldots & t_{1 n} \\
t_{21} & t_{22} & \ldots & t_{2 n} \\
\ldots & \ldots & \ldots & \ldots \\
t_{m 1} & t_{m 2} & \ldots & t_{m n}
\end{array}\right]
$$

Among them, $b_{j}=\vee\left(a_{i=1}^{m} \wedge t_{i j}\right)$

The last step is the normalized analytical processing for the data.

\section{The establishment of the University Marxism education resources evaluation system from the new media perspective}

University Marxism education in the new media perspective resource integration not only reflected the Marxism education based on the idea of education, and more is that the existing Marxism education resources can be fully effective resources to achieve optimal configuration, which makes Marxism education more fully realized play, helping to train the students' Marxism education ideological quality. The University Marxism education resource integration lies not only in the 
existing resources to achieve the full depth of the excavation and development, but also in the light of the new media, a new perspective to explore the Marxism education resources optimal the binding equilibrium point, University Marxism education resources can be optimized play, to achieve effective integration of Marxism education resources is much greater than single Marxism education resources superimposed effect.

This paper discusses mainly from five aspects of University Marxism education: cultural, institutional, material, Marxism education, and network building evaluation system of Marxism education. System embodies Marxism education is mainly focus on the student body reasonable, psychological as well as honest and trustworthy education and humanistic spirit atmosphere of the evaluation in the evaluation of the university legal, ethical, regulatory, and environmental protection, training and education; belief is mainly reflected in the people of faith, patriotism and concern such as international and domestic affairs. The substance is more concerned about care activities of daily code of conduct, and actively participation in community activities. The network is in the application of the new media.

First, we evaluate each of the five factor indicator sequentially. Through cognitive evaluation, we obtain[11]

$F_{\text {System }}=\left(f_{1}, f_{2}, f_{3}, f_{4}\right)=($ Rules, Laws, Re gulation, Internation, Environmentalprotection $)$

The corresponding evaluation set $\mathrm{W}$ is:

Tab.1 Single evaluation factor indicator assessment form

\begin{tabular}{|c|c|c|c|c|}
\hline & $\mathrm{f} 1$ & $\mathrm{f} 2$ & $\mathrm{f} 3$ & $\mathrm{f} 4$ \\
\hline $\mathrm{w}$ & 0.9 & 0.85 & 0.8 & 0.95 \\
\hline
\end{tabular}

Tab. 1 shows that a critical evaluation of a teacher for the students' Marxism education cognition scores are: $0.9,0.85,0.8,0.95$. This can be written as:

$$
\mathrm{T}_{1}=(0.9 、 0.85 、 0.8 、 0.95)
$$

Correspondingly, after making sure other evaluation factor indicators, we can get:

$$
T_{\text {system }}=\left[\begin{array}{cccc}
0.9 & 0.85 & 0.8 & 0.95 \\
0.8 & 0.75 & 0.75 & 0.9 \\
0.9 & 0.8 & 0.8 & 0.85 \\
0.95 & 0.9 & 0.9 & 0.9
\end{array}\right]
$$

So, we can draw a comprehensive evaluation of cognitive.

$$
\begin{aligned}
& B_{\text {system }}=A_{1} T_{\text {system }}=(0.4,0.4,0.3,0.3) \times\left[\begin{array}{cccc}
0.9 & 0.85 & 0.8 & 0.95 \\
0.8 & 0.75 & 0.75 & 0.9 \\
0.9 & 0.8 & 0.8 & 0.85 \\
0.95 & 0.9 & 0.9 & 0.9
\end{array}\right] \\
& =(0.87,0.80,0.815,0.875)
\end{aligned}
$$

Then after other evaluation we obtain:

$$
\begin{aligned}
& B_{\text {culture }}=(0.915,0.85,0.765,0.86) \\
& B_{\text {Material }}=(0.91,0.84,0.965,0.89) \\
& B_{\text {ethics }}=(0.79,0.865,0.76,0.815) \\
& B_{\text {network }}=(0.94,0.87,0.84,0.83)
\end{aligned}
$$

Finally, after the normalization of the indicator of each factor, we can get:

$\mathrm{B}^{\prime}=(0.2033,0.2127,0.2090,0.1950,0.2120)$

This indicates that University students rank first in the area of Marxism education resources, accounting for $21.27 \%$, followed by the network education, accounting for $21.20 \%$, in the third of the material resources, the final is ethics resources, accounting for 19.50\%[12]. These accounted for less; University for five aspects of educational resources are more concerned about a variety of Marxism 
education is relatively flat. But the importance of material and institutional resources is to strengthen ethics, network utilization and cultural resources. This requires more use of new media.

\section{University Marxism education resource integration model analysis from new media perspective}

College Marxism education target is to realize the all-round development of students, cultivate noble social talents with high quality. Colleges and universities Marxism education in ideal and faith education, innovative education, science education, the spirit of honesty education, psychological education, which needs the help of different Marxism education medium. New media in University from the perspective of Marxism education resource integration is needed in cultural construction, material, system construction and Marxismity and education network resource to be used effectively. Such as, in the system of the college teachers and students of legal, ethical, regulations and environmental protection and other aspects of the training and education; strengthen the teacher to student 's physiological, psychological concerns and their honesty and trustworthiness education, create a good atmosphere of the humanities spirit; close attention to students' faith and patriotism, cultivate their pay attention to international and domestic affairs; to cultivate students' caring activities, actively involved in community activities and so on; at the same time, through the new media to achieve people's visual and auditory impact, achieving the time span, the realization of information from the transmitted by the development and innovation, strengthen the students' Marxism education.

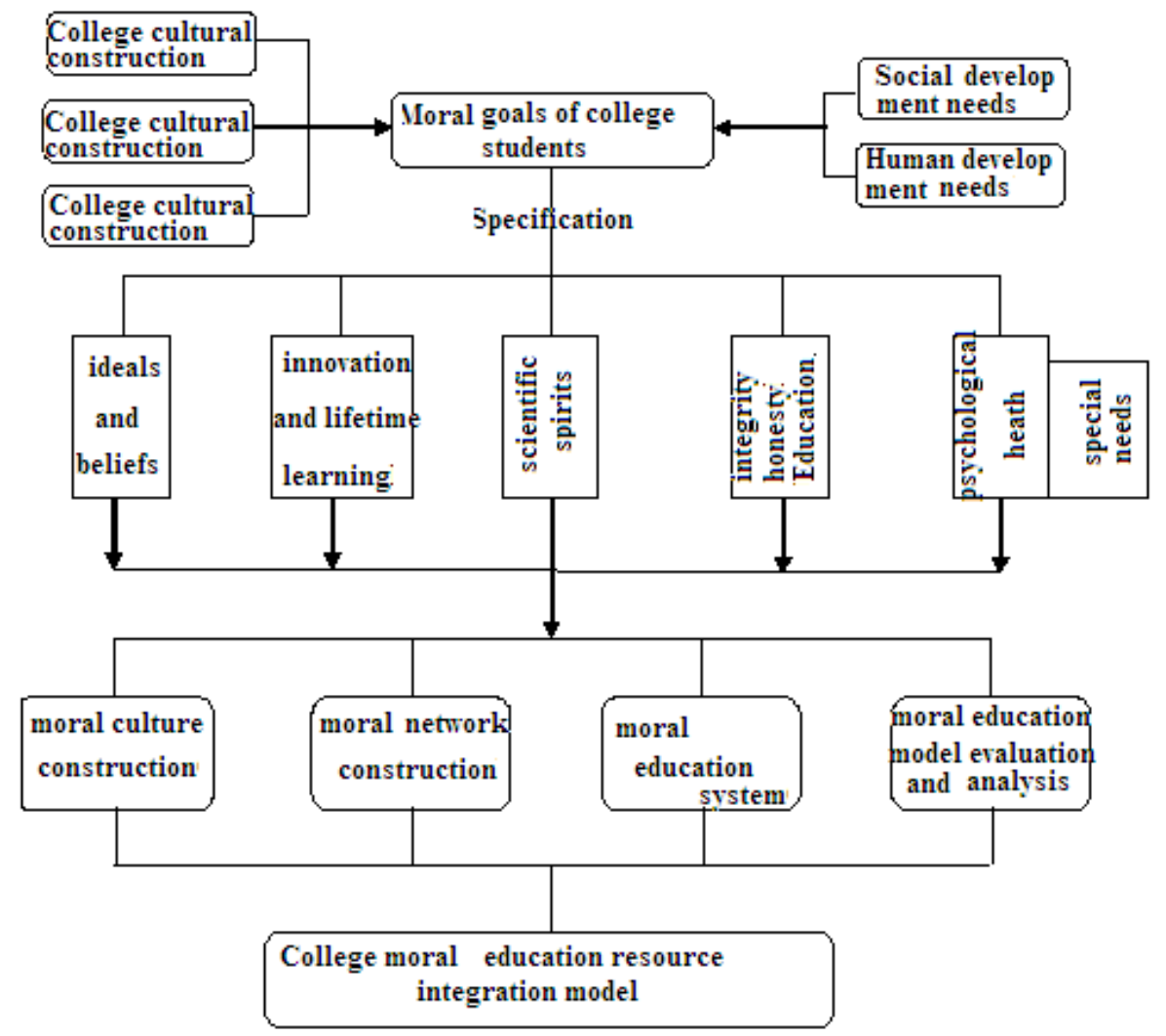

Fig.1 University Marxism education resource integration model Figure from new media perspective

University Marxism education resource integration model from the new media perspective needs making the university's cultural, material, system, and Marxism education, and network resources optimization configuration and integration at the same time, strengthen the campus Marxism education evaluation system is the establishment of a sound and effective implementation of the university Marxism education model evaluation and analysis of the full range of the guidance of the Marxism education of the university, people-oriented culture comprehensive and sustainable development of the students. 


\section{Conclusion}

University Marxism education resources is one of the key elements of the effectiveness of Marxism education in universities. University Marxism education resources are the focus of the community and it is also the focus of this paper on how to realize the resources of the University Marxism education optimization, so that it can play the biggest role. The main content of the paper is in the new media and University Marxism education resources, focusing on University students in Marxism education evaluation to build Marxism education evaluation system for Universities and universities. Meanwhile, we understand the Marxism education status quo and through fuzzy evaluation method statistical analysis to know the status of Marxism education, and target to the establishment of a new media perspective of the University Marxism education resource integration mode, use resources in the society, network as well as Universities and universities to realize resources' effective sharing, in order to achieve the integration of resources and the optimal configuration of resources.

\section{References}

[1] Yi Lianyun, Deng Da. Challenges faced by the new media age comparative education research and selection [J] Comparative Education Research,2010 (05):78-81.

[2] Le Juan. Construction of private Universities and universities’ Marxism education model study [D]. Nanchang University, 2010

[3] Lian Ying, Xu Bing, Liu Yingfei. Challenges of the new media to the Marxism education and Countermeasures [J] Xiang tide (the second half).,2011 (01);73.

[4] Zhou Xianjin. Universityes and universities’ Marxism education environment three main levels

[J]. Ideological and Political Education Research,2009 (01):54-55.

[5] Ke Xiaolan. Ideological and political work in the new media vision challenges and countermeasures [J]. Century bridge, 2009 (09):34-36

[6] Sheng Qizhi, Zhan Cheng. Media literacy survey of University students and media literacy education strategy [J] Northeastern University (Social Sciences) ,2011 (01):26.

[7] Hu Xiaoyun. Hu Jie. The fourth media network strength [J] reporter cradle ,2009 (01):23-25.

[8] Chang Lifei. Marxism education's higher resources and their configuration [J] Modern Education Science ,2010 (01):57-58.

[9] Chen Maosheng. New media and the study of the ideological and political education of the carrier

[D]. Huazhong Normal University, 2009

[10] Cao Fengcai, Tian Weifei. New media age University students’ Marxism education thinking [J]., North University of Technology (Social Sciences),2012 (06):77-78.

[11] Xiao Liangliang, Chang Xiaoli. How to effectively integrate the University media and give full play to the function of educating people [J] legal system and society, 2009 (22):53-54.

[12] Xu Zhenxing. Rethinking of strengthening University students’ network Marxism education [J]. School Party building and ideological education (the first half),2010 (08):49-51. 